\title{
Contested Numbers: Census Controversies and the Press in 1960s Nigeria
}

\author{
Gerardo Serra* (D) and Morten Jerven \\ University of Manchester and Norwegian University of Life Sciences \\ ${ }^{\star}$ Corresponding author. E-mail: gerardo.serra@manchester.ac.uk
}

(Received 22 March 2018; revised 21 June 2021; accepted 2 July 2021)

\begin{abstract}
This article reconstructs the controversies following the release of the figures from Nigeria's 1963 population census. As the basis for the allocation of seats in the federal parliament and for the distribution of resources, the census is a valuable entry point into postcolonial Nigeria's political culture. After presenting an overview of how the Africanist literature has conceptualized the politics of population counting, the article analyses the role of the press in constructing the meaning and implications of the 1963 count. In contrast with the literature's emphasis on identification, categorization, and enumeration, our focus is on how the census results informed a broader range of visual and textual narratives. It is argued that analysing the multiple ways in which demographic sources shape debates about trust, identity, and the state in the public sphere results in a richer understanding of the politics of counting people and narrows the gap between demographic and cultural history.
\end{abstract}

Keywords: Nigeria; West Africa; demography; governance; identity; ethnicity; state

Population censuses offer data on which the formulation and testing of hypotheses on issues such as labour markets, fertility, religion, service delivery, taxation, and health rely. Population counting is also a landmark of state sovereignty, located at the intersection of 'the political project of developing the administrative infrastructure and authority of a modern state, the cultural project of constructing the communal bonds... of a modern nation, and the scientific project of producing useful knowledge about the population'. ${ }^{1}$ Scholars in African studies have interrogated censuses to assess the reliability of demographic statistics, to shed light on the working of states, and to investigate questions of power and identity. ${ }^{2}$ Yet this literature's emphasis on data quality and on the ways in which census forms and enumeration practices 'constructed' ethnic and racial categories has prevented a broader assessment of the place of population counting in the political culture of the postcolonial state. This paper suggests that the circulation, appropriation, and contestation of census figures in the press represent productive avenues for the historicization of the politics of counting people.

Nigeria represents an ideal setting for reflection on this issue. Indeed, in Africa's most populous country the census has been (and continues to be) a politically explosive issue. As the basis of

\footnotetext{
${ }^{1}$ M. Loveman, 'Race to progress: census taking and nation making in Brazil (1870-1920)', Hispanic American Historical Review, 89:3 (2009), 438-9.

${ }^{2}$ These strands of literature will be discussed in more detail in later sections, but insightful examples of these approaches include B. Fetter, 'Decoding and interpreting African census data: vital evidence from an unsavory witness', Cahiers d'Études africaines, 27:105/106 (1987), 83-105; M. Mamdani, When Victims Become Killers: Colonialism, Nativism, and the Genocide in Rwanda (Princeton, 2002), 99-102; K. Weitzberg, 'The unaccountable census: colonial enumeration and its implications for the Somali people of Kenya', The Journal of African History, 56:3 (2015), 409-28.

(C) The Author(s), 2021. Published by Cambridge University Press. This is an Open Access article, distributed under the terms of the Creative Commons Attribution licence (http://creativecommons.org/licenses/by/4.0/), which permits unrestricted re-use, distribution, and reproduction in any medium, provided the original work is properly cited.
} 
parliamentary representation and the allocation of amenities and social services, the census has been a pivotal element in the social contract linking the federation, the states composing it, and the citizenry. It has also been a powerful catalyst for the articulation of narratives about identity, ethnicity, and the viability of Nigeria as a nation-state. Following a review of how Africanists have looked at census taking, we use the controversies surrounding the 1963 census as a lens to identify and analyse different ways in which the meanings and implications of the census were articulated. Inspired by the rich historiography on African print cultures, this article explores the ways in which newspapers and pamphlets rearticulated the political meanings and implications of the count. ${ }^{3}$ Although grounded in Nigerian specificities, this exercise points to the importance of going beyond a conceptualization of the politics of census taking that focuses on statistical categorization or on the political economy of numbers, in favour of analysing the wider range of media and representations through which demographic figures shape public debates.

\section{Census taking in Nigerian and African history}

\section{From data quality to the political economy of numbers}

There are several possible ways of historicizing census taking in Africa. ${ }^{4}$ One avenue is to interpret the census as a source for demographic history and thus treat its evolution as the starting point of a reflection on data quality. Between the late nineteenth century and independence around 1960, colonial regimes across the continent produced several attempts to count their subjects for purposes of taxation, military conscription, and the acquisition of knowledge for use in policy making. ${ }^{5}$ However, the quality of the data in colonial censuses was often dubious. Contemporary sources describe the persistent administrative and political challenges associated with counting people, including a lack of staff and funding, low state capacity, and the reluctance and resistance of the enumerated people - often depicted as resulting from a mixture of African 'cultural taboos', 'ignorance and superstition', and fear of taxation. ${ }^{6}$ As a consequence, demographers have intensely debated the possible uses (as well as limitations) of colonial censuses for reconstructing Africa's demographic past. With reference to the Belgian Congo, Northern Rhodesia, and Nyasaland, Bruce Fetter noted that, in spite of being poor guides for an estimation of the magnitude of a country's population, colonial censuses are useful tools for making inferences about its structure. They thus contribute to the debate on the impact of colonial rule on living standards. ${ }^{7}$ More recently, Ewout Frankema and Morten Jerven turned to the history of census taking in colonial and postcolonial Africa to reassess the continent's demographic evolution. Besides suggesting an upward revision of total population figures, they also reiterated that colonial censuses should not be

\footnotetext{
${ }^{3}$ A recent example is D. R. Peterson, E. Hunter, and S. Newell (eds.), African Print Cultures: Newspapers and Their Publics in the Twentieth Century (Ann Arbor, MI, 2016).

${ }^{4}$ For a classification of 'genres' in the historiography of statistics, see A. Desrosières, 'L'histoire de la statistique comme genre: style d'écriture et usages sociaux', Genèses, 39 (2000), 121-37.

${ }^{5}$ Demographic enquiries were complemented by other censuses. See, for example, the unpublished 1944 census of beggars in Lagos in National Archives of Nigeria, Ibadan, COMCOL 797/I, vols. 1-2. In some areas, population counting and recording for religious and tax-related purposes predated colonial rule. T. E. Bowdich, Mission from Cape Coast Castle to Ashantee (3rd edn, London, 1966 [1819]), 300; I. Wilks, Asante in the Nineteenth Century: The Structure and Evolution of a Political Order (Cambridge, 1975), 80; J. Thornton, 'Demography and history in the kingdom of Kongo, 1550-1750', The Journal of African History, 18:4 (1977), 507-30.

${ }^{6}$ The National Archives of the UK, London (TNA) CO 852/1078/2, 'Conference of statisticians of countries south of the Sahara (draft report)', Salisbury, Southern Rhodesia, 30 July to 7 Aug. 1951; R. Kuczynski, Demographic Survey of the British Colonial Empire, 3 Volumes (London, 1948-53), especially Volume I, West Africa (1948) and Volume II, South Africa High Commission Territories, East Africa, Mauritius, Seychelles (1949). Contemporary assessments of Nigerian colonial censuses include M. Perham, 'The census of Nigeria, 1931', Africa, 6:4 (1933), 415-30; and R. Mansell Prothero, 'The population census of Northern Nigeria 1952: problems and results', Population Studies, 10:2 (1956), 166-83.

${ }^{7}$ Fetter, 'Decoding and interpreting'.
} 
dismissed altogether as sources for the magnitude of Africa's population. ${ }^{8}$ They further stressed the importance of analysing state capacity and the incentives faced by census takers and enumerated subjects (alongside more consolidated interpretations of demographic evidence and intercensal growth rates) as determinants of the validity and reliability of population figures. ${ }^{9}$

The political economy of numbers has occupied a prominent role in the extensive literature on Nigeria, where counting people has largely taken place within a set of incentives that associated expected benefits with the inflation of population figures. ${ }^{10}$ Given the importance of population returns for federal parliamentary representation and the allocation of federal revenues and social services, it is not surprising that Nigerian census results have been hotly contested. Since the 1950 s, this contributed to the institutionalization and reinforcement of a divisive political imagination that posited the (predominantly) Muslim 'North' against the (predominantly) Christian 'South', while on the other hand problematizing the relationship between ethnic identities and the acquisition of power to rule over 'others'. The enduring influence of the last colonial census can be observed in the strong reactions to the declaration of Harold Smith, a former colonial civil servant employed by the Department of Labour, that the figures of the last colonial census in 1952 had been inflated to guarantee that the North had more than 50 per cent of the total population. ${ }^{11}$ Arguably, this was the consequence of British perceptions of the North as more collaborative and conservative, compared to other regions that were seen as subversive sites of nationalist agitation. While their veracity is contested, Smith's claims reiterate the centrality of the census as a catalyst of tensions in postcolonial Nigeria and point to the long shadow of the colonial political economy. ${ }^{12}$ Did the existence of strong incentives to inflate the figures (and the fact that instances of inflation have been documented in the case of specific communities) mean that misreporting happened on a systematic basis? On the basis of demographic tests and political economy considerations, most scholars agree that this has indeed been the case. ${ }^{13}$ So, too, does the

\footnotetext{
${ }^{8}$ Contrast E. Frankema and M. Jerven, 'Writing history backwards or sideways? Towards a consensus on African population, 1850-2010', in G. Austin and S. Broadberry (eds.), special issue 'The renaissance of African economic history', The Economic History Review, 67:4 (2014), 907-31; with P. Manning, 'African population: projections, 1850-1960', in K. Ittmann, D. Cordell, and G. Maddox (eds.), The Demographics of Empire: The Colonial Order and the Creation of Knowledge (Athens, OH, 2010), 245-75.

${ }^{9}$ Frankema and Jerven, 'Writing history backwards', 911.

${ }^{10}$ Censuses were undertaken in 1921, 1931, 1952, 1962, 1963, 1973, 1991, and 2006. An excellent introduction is M. Iro, The Population Censuses of Nigeria from Colonial Times: An Evaluation of their Coverage and Accuracy (Okigwe, Nigeria, 1987). For a long-term view on population and economic growth, see M. Jerven 'Controversy, facts and assumptions: lessons from estimating long term growth in Nigeria, 1900-2007', African Economic History, 46:1 (2018), 104-36.

${ }^{11}$ Smith made these claims several times: as part of Mike Thompson's 'Rigging Nigeria' on BBC Radio 4, and as a guest of different programmes on Nigerian television. Smith's interview with Ben Television can be found here: https://www.youtube. $\mathrm{com} /$ watch? $\mathrm{v}=\mathrm{Xb} 62 \mathrm{WT} 41 \mathrm{mnE}$.

${ }^{12}$ P. Brimah, 'Debunked: the Harold Smith Nigeria census lies', Sahara Reporters, 10 Dec. 2013, (http://saharareporters.com/ 2013/12/10/debunked-harold-smith-nigeria-census-lies). Responses to Smith's 'confession' ranged from appreciation for his confirming widely held assumptions to accusations that he was 'a hired agent' telling 'a bunch of lies'. Contrast T. Akinola, 'He fought our battle, that is why we are grateful to him', 4 Jan. 2011, (https://haroldsmithmemorial.wordpress.com/harold-smith-foughtour-battle); with Alhaji T. Yakasai, 'Did Britain manipulate pre-independence polls in favour of North?', Daily Trust, 10 Jul. 2020, (https://dailytrust.com/did-britain-manipulate-pre-independence-polls-in-favour-of-north). Yakasai was a key figure of the Northern Elements Progressive Union (NEPU) in the 1950s. Beyond the blogosphere, see C. Achebe, There Was a Country: A Personal History of Biafra (London, 2012).

${ }^{13}$ Studies arguing for the wild inflation of population figures include S. Aluko, 'How many Nigerians? An analysis of Nigeria's census problems, 1901-1963', The Journal of Modern African Studies, 3:3 (1965), 371-92; I. Ekanem, The 1963 Nigerian Census: A Critical Appraisal (Benin City, Nigeria, 1972); A. Okolo, 'The Nigerian census: problems and prospects', American Statistician, 53:4 (1999), 321-5. Others produced alternative estimates suggesting that the Nigerian population around the time of the 1963 count was lower than the census figure. See I. Eke, 'Population of Nigeria: 1952-1965', The Nigerian Journal of Economic and Social Studies, 8:2 (1966), 289-310; and C. Okonjo, 'A preliminary medium estimate of the 1962 mid-year population of Nigeria', in J. Caldwell and C. Okonjo (eds.), The Population of Tropical Africa (London, 1968), 78-96. Even before the publication of his classic academic article, Aluko had already voiced in the daily
} 
National Population Commission, which in its report on the 2006 census admitted that 'varying degrees of overenumeration of population was rampant throughout the country coupled with omission of certain settlements in the earlier census exercises, and this possibly contributed much to the unacceptability of the census. ${ }^{14}$ However, other commentators, most notably the demographer Paul Olusanya, emphasized in the 1980s that the 'problems of population enumeration in Nigeria are largely problems of under-development, of ignorance, of mass illiteracy. Even if there was no political rivalry, our data gathering efforts would still be vitiated by more important factors. ${ }^{15}$ The 2006 census has shown that the removal of questions on ethnicity and religion and the introduction of new technologies, such as the Global Positioning System (GPS) and optical mark and character recognition software for the reading and processing of questionnaires, was not enough to avoid controversy. ${ }^{16}$ Furthermore, that count was allegedly still affected by logistical and organizational challenges. $^{17}$

Focusing, as most scholarly literature on the Nigerian census does, on the relationship between the federal government and the states misses other crucial aspects of the political economy of population figures. Indeed, the benefits resulting from the inflation of figures were conducive to the creation of new patterns of inequality that can only be observed by 'zooming in' and looking at the life of specific towns and local communities, as shown by the experience of different towns in southwestern Nigeria during the 1962 and 1991 censuses. ${ }^{18}$ But communities' attempts to shape the outcomes of the censuses not only targeted population figures but also involved a wider array of social practices, including deliberate modification - and sometimes defacing - of public spaces. Relying on what his father told him, an informant reported in 2019 that shortly before the 1963 census 'in Lagos Island . . public taps were vandalised. ${ }^{19}$ Similarly, even though the government had transformed the Ajele cemetery into a playground where 'people used to go and play football and have races', 'just before the census came they started bringing some tombstones back [from Ikoyi, where the cemetery had been relocated] to the place to say it [the playground] wasn't existing.' By defacing the playground, the perpetrators of this act wanted to give the enumerators a distorted view of reality that they hoped would translate into additional amenities for their community. ${ }^{20}$ Although at this initial stage of our research it is premature to comment on the representativeness of practices such as this (in Lagos and elsewhere), this anecdote is a powerful reminder of how little we know of the multiple ways in which the Nigerian census was understood, negotiated, and mobilized for political and economic gain.

Even accounting for this multiplicity, there is a crucial difference between the political economy of census taking and that of other forms of quantification, such as registration and vital statistics, which have attracted much attention in recent years. ${ }^{21}$ While both can function as claims to

press his doubts on the accuracy of 1963 census. The Northern press accused him of politicizing the count and spreading alarm; see 'Shut up, Dr. Aluko!', Nigerian Citizen, 26 Oct. 1963, 1.

${ }^{14}$ 'Report of Nigeria's National Population Commission on the 2006 Census', Population and Development Review, 33:1 (2007), 207. States' distrust of the federal figures, or dissatisfaction with the results, could lead them to conduct their own parallel censuses, as happened in Lagos State during the 2006 count. Thanks to Olutayo Adesina for pointing this out.

${ }^{15}$ P. Olusanya, Nigeria's Demographic Delusion: A Critical Examination of the Census Controversy (Lagos, 1983), 29; B. Ahonsi, 'Deliberate falsification and census data in Nigeria', African Affairs, 87:349 (1988), 553-62.

${ }^{16}$ On the background to the 2006 count, see O. Obono and E. Omoluabi, 'Technical and political aspects of the 2006 Nigerian population and housing census', African Population Studies, 27:2 (2014), 249-62.

${ }^{17}$ R. Lalasz, 'In the news: the Nigerian census', Population Reference Bureau, 1 Apr. 2006.

${ }^{18}$ T. Eighmy, Problems of Census Interpretation in Developing Countries: The Western Nigeria Case (Lund, Sweden, 1968), 166-7; E. Renne, 'Nigeria's demographic delusion - a 1991 census exercise in a southwestern Nigerian town', in J. Edigbola and E. Renne (eds.), Population and Development Issues: Ideas and Debates - Essays in Honour of Professor P. O. Olusanya (Ibadan, 2000), 303-20; E. Renne, Population and Progress in a Yoruba Town (Edinburgh, 2001), 175-96.

${ }^{19} \mathrm{G}$. Serra's interview with F. I., Ibadan, 8 Apr. 2019.

${ }^{20}$ Ibid.

${ }^{21}$ F. Cooper, 'Voting, welfare and registration: the strange fate of the État-Civil in French Africa, 1945-1960', in K. Breckenridge and S. Szreter (eds.), Registration and Recognition: Documenting the Person in World History (Oxford, 
entitlement vis-à-vis the government, the latter can also grant benefits - and pose risks - to families and individuals, rather than just to demographic cohorts or larger communities. ${ }^{22}$ Historically, the perception associated with documenting births and deaths has been profoundly asymmetrical, with the former seen as more likely to produce entitlements. ${ }^{23}$ An exception to this can be observed in contemporary Kaduna, where the closures of textile mills led dismissed workers and their families to set up the Coalition of Closed Unpaid Textile Workers Association Nigeria. The assemblage of lists of dead workers (with individual names and dates of death) became a lynchpin of the community's discursive and political response to the hardship caused by the mill closures. Indeed these mortality data, produced by the widows of the dead workers and other actors associated with the coalition, became 'an important step for clarifying the socioeconomic impact of textile mill closures, deindustrialization, and unemployment'. ${ }^{24}$ Being mobilized as tools 'to put pressure on the government and textile mill management to live up to their agreement to pay workers' remittances', these lists simultaneously allow widows and other coalition members to 'commemorate the dead and employ their names for the benefit of the living. ${ }^{25}$ The mutual construction of the practice of listing and documenting individual deaths, mourning, remembering, and claiming monetary compensation suggests that, while crucial, the political economy of numbers is only one of the dimensions of the politics of counting people.

\section{Imagined communities, categories, and agency}

Drawing on an intellectual genealogy that sees the work of Michel Foucault, Benedict Anderson, and James Scott as crucial nodal points, recent histories of the phenomenon of the census, no longer confined to the domains of political economy and historical demography, have reflected instead on the conceptual categories employed by colonial states as disciplinary tools of governance or as instruments of nation making. ${ }^{26}$ Yet, as shown by the case of Somali communities in Kenya, histories of colonial statistics illuminate the epistemic and administrative constraints faced by colonial states. ${ }^{27}$ The combination of porous borders, nomadic lifestyle, lack of perceived economic potential, and low political priorities attached to the North Eastern Province of Kenya led the colonial administration to see the Somalis as 'less legible' than other communities and to devote few

2012), 277-96; S. Doyle, 'Parish baptism registers, vital registration and fixing identities in Uganda', in Breckenridge and Szreter, Registration and Recognition, 357-83; K. Breckenridge, 'No will to know: the rise and fall of African civil registration in twentieth-century South Africa', in Breckenridge and Szreter, Registration and Recognition, 385-412.

${ }^{22}$ On the differences between enumeration and registration, see S. Szreter and K. Breckenridge, 'Editors' introduction: recognition and registration; the infrastructure of personhood in world history', in Breckenridge and Szreter, Registration and Recognition, esp. 7, 18-19.

${ }^{23}$ In some cases, this was also the direct consequence of colonial policy. In Uganda, for example, 'the fine for failing to register a birth was twenty times greater than that for the non-registration of a death.' Doyle, 'Parish baptism registers', 279.

${ }^{24} \mathrm{E}$. Renne, Death and the Textile Industry in Nigeria (London, 2020), 9.

${ }^{25}$ Ibid. 13,3 .

${ }^{26}$ M. Foucault, Security, Territory, Population: Lectures at the College de France, 1977-1978 (Basingstoke, UK, 2007); M. Foucault, The Birth of Biopolitics: Lectures at the College de France, 1978-1979 (Basingstoke, UK, 2008); B. Anderson, Imagined Communities: Reflections on the Origin and Spread of Nationalism (3rd edn, London, 2006 [1983]), 164-70; J. Scott, Seeing like a State: How Certain Schemes to Improve the Human Condition Have Failed (New Haven, 1998). On the other hand, it has been claimed that the 'postmodern' and 'postcolonial' emphasis on categorization and power might have undermined African historical demography; see D. Cordell, 'African historical demography in the postmodern and postcolonial eras', in Ittmann, Cordell, and Maddox, Demographics of Empire, 22-58. While the colonial period remains the focus of most studies on the history of the census in Africa, there are recent exemptions that analyse demographic statistics to illuminate of the early years of independence. See L. Barré, 'Compter pour planifier: dénombrement de la population et "capitalisme d'État” en Côte d'Ivoire (1954-1967)', in B. Samuel (ed.), special dossier 'Raisons et imaginaires de la planification', Politique africaine, 1 (2017), 109-28; G. Serra, "Hail the census night": trust and political imagination in the 1960 population census of Ghana', Comparative Studies in Society and History, 60:3 (2018), 659-87.

${ }^{27}$ Weitzberg, 'The unaccountable census'. 
resources to the collection of accurate population figures on them. Although it had the potential to fashion the 'imagined community' of the nation state, in practice the colonial census consolidated inequalities in the government's perception of different ethnic groups. This, in turn, justified and exacerbated the unevenness underpinning the construction of statistical knowledge about different categories. ${ }^{28}$ More generally, the significant gap between the colonial state's ambition to make societies 'legible' through demographic knowledge and its limited capacity to intervene on the ground calls into question the applicability of James Scott's notion of 'seeing like a state'. ${ }^{29}$ With reference to colonial Nigeria (but not with reference to the census), the point has been forcefully made by Steven Pierce, who concludes that the process of 'state formation is not one of a government coming to "see like a state" but rather of a transformation that enabled it to look like one'. ${ }^{30}$

A significant strand in the literature on census taking has emphasized the capacity of the census to remake, rather than simply describe, identities. ${ }^{31}$ In Africanist historiography, the focus has been primarily on the statistical construction of religious and ethnic identities under colonial rule and its legacies. The importance of this enterprise found its most tragic justification in the genocide perpetrated by the Hutu against the Tutsi in Rwanda. In his influential When Victims Become Killers, Mahmood Mamdani stressed the crucial role of the censuses held under the Belgian administration in constructing and institutionalizing these ethnic categories. ${ }^{32}$ If Rwanda and Burundi are among the 'very few countries where social constructivist expectations regarding identity and category seem to be so well verified', discussions about ethnicity in Nigeria have not attributed a prominent role to colonial census taking. ${ }^{33}$ On the other hand, one of the fundamental aims of the 1921 census of Nigeria was precisely the creation of an ethnic map. ${ }^{34}$ Recent literature has focused on rescuing African voices and agencies rather than documenting the interiorisation of statistical categories. As shown in the case of the forest zone in 1920s northern Gabon, a possible approach consists in stressing the profound ontological and epistemic alterity of the colonisers' understanding of famine and depopulation by contrasting it with the narratives through which the local populations made sense of the same phenomena. ${ }^{35}$ Similarly, as discussed with reference to the Western Ijo, Nigeria provides a rich setting for the observation of the disjunction between the concept of household adopted by the statistical apparatus and that used by the counted subjects. ${ }^{36}$ Taking a middle

\footnotetext{
${ }^{28}$ Nor was the mutual construction of political and economic inequalities and 'statistical unevenness' limited to census taking. See, for example, G. Serra, 'An uneven statistical topography: the political economy of household budget surveys in late colonial Ghana, 1951-57', in M. Jerven (ed.), special issue 'Measuring African development: past and present', Canadian Journal of Development Studies/Revue canadienne d'études du développement, 35:1 (2014), 9-27.

${ }^{29}$ Scott, Seeing Like a State. On the other hand, the 'weakness' of colonial states should not be mistaken for lack of coercive power. This is particularly evident in the case of French West Africa, where the production of demographic evidence informed highly disruptive forced labour schemes. On the history of demography in French colonial Africa, see R. Gervais and I. Mandé, 'Comment compter les sujets de l'Empire? Les étapes d'une démographie impériale en AOF avant 1946', Vingtième Siècle: Revue d'histoire, 95:3 (2007), 63-74.

${ }^{30} \mathrm{~S}$. Pierce, 'Looking like a state: colonialism and the discourse of corruption in Northern Nigeria', Comparative Studies in Society and History, 48:4 (2006), 909-10.

${ }^{31}$ For example, see the essays in D. Kertzer and D. Arel (eds.), Census and Identity: The Politics of Race, Ethnicity, and Language in National Censuses (Cambridge, 2002).

${ }^{32}$ Mamdani, When Victims Become Killers, 99-102.

${ }^{33} \mathrm{P}$. Uvin, 'On counting, categorizing and violence in Burundi and Rwanda', in Kertzer and Arel, Census and Identity, 148. Given our emphasis on representation of Igbo and Hausa-Fulani identities in the press, see especially A. Harneit-Sievers, Constructions of Belonging: Igbo Communities and the Nigerian State in the Twentieth Century (Rochester, NY, 2006); A. Haour and B. Rossi (eds.), Being and Becoming Hausa: Interdisciplinary Perspectives (Leiden, 2010).

${ }^{34}$ For further discussion, see D. van den Bersselaar, 'Establishing the facts: P.A. Talbot and the 1921 census of Nigeria', History in Africa, 31 (2004), 69-102.

${ }^{35} \mathrm{~J}$. Cinnamon, 'Counting and recounting: dislocation, colonial demography, and historical memory in northern Gabon', in Ittmann, Cordell, and Maddox, Demographics of Empire, 130-56.

${ }^{36} \mathrm{M}$. Hollos, 'Why is it difficult to take a census in Nigeria? The problem of indigenous conceptions of households', Historical Methods, 92:25 (1992), 12-19. Conceptual difficulties when dealing with African households were not exclusive to census takers; see J. Guyer, 'Household and community in African studies', African Studies Review, 24:2/3 (1981), 87-137.
} 
ground between the two extremes of 'interiorization' and 'epistemic alterity', the census can be treated as a site of encounter and mediation between representatives of the state and its subjects. In this process, identities and statistical categories are not unequivocally imposed, but rather strategically negotiated. This was the case, for example, in southern Mali in the 1940s and 1950s, when communities that largely sustained indigenous religious practices self-identified as Muslims. ${ }^{37}$ While this self-identification echoed an ancient way of dealing with stronger Muslim powers, through the census it became a strategy to navigate the new uncertainties associated with colonial rule. ${ }^{38}$

However, it would be inaccurate to limit the realm of census-led agency to identity appropriation and self-identification. Resistance and contestation are deeply embedded in the history (and historiography) of demographic knowledge. ${ }^{39}$ While Africanists have repeatedly emphasized the contested status of population figures, an analysis of the concrete modalities by which demographic statistics were received and challenged is virtually absent from the extensive literature on resistance and African civil society. ${ }^{40}$ The focus has been on resistance to being counted (especially in colonial times) or on the consequences of census figures for economic development and political representation, rather than on the specific forms of their contestation. ${ }^{41}$ In contrast, histories of statistics in other parts of the world provide a rich departure point from which to think about how resistance to the census, or the critical reception of demographic numbers, become intertwined with the production and circulation of textual and visual artefacts in the public sphere. ${ }^{42}$ Indeed, social and cultural histories of census taking make extensive use of the press. ${ }^{43}$ Their exploration of statistics in the public sphere raises interesting questions about numbers' capacity to inspire people's trust, 'transform public conceptions of authority and accountability', and 'permeate political debate. ${ }^{44}$ Inspired by this literature, the remaining part of this paper analyses how the press 'made' the 1963 Nigerian census. Through a close reading of daily newspapers and pamphlets published in different parts of Nigeria, the article treats the census as an entry point into the 'multiplication of modes of constituting textual meanings and imagining communities' associated with print cultures. ${ }^{45}$ The journey across different genres, formats, and reading publics reveals the plasticity of the census in Nigerian political imagination and documents its capacity to both consolidate and subvert the 'imagined community' of the nation.

\section{Population figures and the balance of power}

At the time of independence in October 1960, Nigeria's parliamentary democracy appeared fragmented along ethnic and religious lines. The political landscape was dominated by three parties,

\footnotetext{
${ }^{37}$ B. Peterson, 'Quantifying conversion: a note on the colonial census and religious change in postwar southern Mali', History in Africa, 29 (2002), 391.

${ }^{38}$ Ibid.

${ }^{39}$ An early example is D. Glass, 'The population controversy in eighteenth century England. Part I. The background', Population Studies, 6:1 (1952), 69-91.

${ }^{40}$ See for example E. Obadare and W. Adebanwi (eds.), Encountering the Nigerian State (New York, 2010).

${ }^{41}$ For example, Weitzberg, 'Unaccountable census'.

${ }^{42}$ M. Anderson, The American Census: A Social History (New Haven, 1988), esp. ch. 6; M. Anderson, 'The census, audiences and publics', Social Science History, 32:1 (2008), 1-18; M. Hannah, Dark Territory in the Information Age: Learning from the West German Census Controversies of the 1980s (London, 2010); K. Levitan, A Cultural History of the British Census: Envisioning the Multitude in the Nineteenth Century (New York, 2011); J. Liddington, Vanishing for the Vote: Suffrage, Citizenship and the Battle for the Census (Manchester, 2014).

${ }^{43}$ Many of these studies draw from Jürgen Habermas' emphasis on the popular press as a key site for the construction of a public sphere mediating between civil society and the state. See J. Habermas, The Structural Transformation of the Public Sphere: An Enquiry into a Category of Bourgeois Society (Oxford, 2002 [1969]).

${ }^{44}$ T. Crook and G. O'Hara, 'The "torrent of numbers”: statistics and the public sphere in Britain, c. 1800-2000', in T. Crook and G. O'Hara (eds.), Statistics and the Public Sphere: Numbers and the People in Modern Britain, c. 1800-2000 (New York, 2011), 3.

${ }^{45} \mathrm{~K}$. Barber, The Anthropology of Texts, Persons and Publics: Oral and Written Culture in Africa and Beyond (Cambridge, 2007), 145. Italics in the original.
} 
each finding its main source of support in the ethnic groups that dominated the different regions of Nigeria: Nnamdi Azikiwe's (and, later, Michael Okpara's) National Council of Nigeria and the Cameroons (NCNC, which later stood for National Convention of Nigerian Citizens) in the Igbo-dominated southeast, Chief Ọbafẹ́mi Awólọ́wọ̀s (and later Chief Samuel Akíntọ́lá’s) Action Group (AG) in the Yoruba-dominated southwest, and Sir Ahmadu Bello's Northern People Congress (NPC) in the Hausa-Fulani dominated North. ${ }^{46}$ At independence, the NCNC was allied with the NPC, while the AG was the main opposition party. As it will be shown, the 1962 and 1963 counts played an important role in altering the relationships between key political stakeholders. Besides serving as the basis for social and economic planning, the 1962 census was also supposed to provide the basis on which a new electoral roll would be compiled for the 1964 federal election: after being counted, each eligible person would receive a voter's card. ${ }^{47}$

What made the results of the 1962 census politically explosive was the fact that, for the first time in Nigeria's statistical history, the North had less than 50 per cent of the total population of the country, which could have implied the loss of an absolute majority in the House of Representatives. The situation was intensified by the fact that the Daily Express, a Lagos-based daily, published some 'unofficial' figures which gave to the North a population of 11 million, thus bringing it close to the results of the 1931 census. ${ }^{48}$ But this, as commented by David Muffett in the 1960s (who, given his involvement in the 1952 census in the Northern Region, had a vested interest in defending the results of the last colonial census), amounted to an argument 'that the 1952 figures must have been 65\% inaccurate, or that a holocaust of epidemic proportions had occurred in the intervening years, which could have hardly gone unnoticed'. ${ }^{49}$ It is as part of this anxiety over the Northern figure that we should understand the accusation voiced by the Eastern press that, even after the 1962 figures became common knowledge, counting was still going on in the North. Whether or not this was true, Federal Minister of Economic Development Waziri Ibrahim, a businessman from Borno State, claimed that the Northern population could have been around 22 or 30 million people. ${ }^{50} \mathrm{~A}$ member of the Eastern House of Assembly interpreted this as an admission that, by recounting (or continuing to count), the North was actually 'looking' for the 'missing' people. ${ }^{51}$ Whether or not this was the case, the final report on the 1962 count submitted by the federal census officer to the cabinet allegedly provided a reestimated figure of 30 million people for northern Nigeria. ${ }^{52}$ Nonetheless, the federal census officer's claim that the 1962 returns were false rested primarily on the East's returns being too high (and the population growth since the 1952-3 count being too fast compared with that of other regions) and the fact that the Western Region had submitted returns for only 5 out of 62 divisions. ${ }^{53}$ Indeed, the census took place at a time when two competing visions for the Western Region and its

\footnotetext{
${ }^{46}$ Despite the centrality of these three parties, the political landscape was much more complex for three interrelated reasons. Firstly, many ethnic minorities were establishing their own parties and pushing for greater autonomy and for the creation of additional states. Secondly, even in their regional stronghold, the dominance of the three main parties was far from absolute. Thus, for example, in the North the NPC was challenged by the Northern Elements Progressive Union and the United Middle Belt Congress. Finally, the alliances between the three main parties were fluid and precarious. A classic introduction is L. Diamond, Class, Ethnicity and Democracy in Nigeria: The Failure of the First Republic (Basingstoke, UK, 1988).

${ }^{47}$ For an appraisal of the 1962 census and the reasons that led to its abandonment, see Aluko, 'How many Nigerians?', $377-84$.

${ }^{48 ،}$ Census results shocker', Daily Express, 2 Aug. 1962, 1.

${ }^{49}$ D. Muffett, 'The politics of census taking in Nigeria', Center for International Affairs, Harvard University (n.d., ca. 1964), 39.

${ }^{50}$ Aluko, 'How many Nigerians?', 384.

${ }^{51}$ The speech is quoted in Muffett, 'Politics of census taking', 41-3.

${ }^{52}$ Aluko, 'How many Nigerians?', 384.

${ }^{53} \mathrm{~T}$. Yesufu, 'The politics and economics of Nigeria's population census', in Caldwell and Okonjo, Population of Tropical Africa, 106-16, 107. Population growth is presented in Table 1. In contrast, for a defence of the 1962 Eastern figures, see Okonjo, 'Estimate', 82-3.
} 
place within the federal order confronted each other. The rivalry between Awólộoọ and Akíntọ́lá resulted in a parliamentary crisis. ${ }^{54}$

The 1962 count began in May, at the time when the federal government declared the state of emergency. The Prime Minister Abubakar Tafawa Balewa announced the need for a second count. Balewa reiterated that the census would provide the basis for an updated electoral register for the 1964 federal election and remarked that the count was 'a call to national duty'. ${ }^{55}$ Unlike its predecessor, which stretched over two weeks, the 1963 census took place over only four days (5-8 November) in order to limit internal migration and double counting. The responsibility for the census was removed from the Ministry of Economic Development and the regional governments and allocated to a newly created institution, the Census Board. Its membership was comprised of United Nations statistical experts and representatives of all the different regions of the federation. ${ }^{56}$ With the employment of almost 150,000 enumerators and costing around $£ 2.5$ million, the new count was the largest and most expensive statistical inquiry in the history of the country.

The 1963 census gave the North a much larger figure of 29.8 million, thus marking its return to being recognized as having an absolute majority of Nigeria's population. With a figure of 12.39 million, the East now accounted for only 22 per cent of the total population (in contrast with the 27 per cent resulting from the 1962 census). Michael Okpara, the Eastern Region's new premier, declared the figures 'worse than useless'. ${ }^{57}$ The census marked a dramatic point in the deteriorating relationship between the NPC and the NCNC. The latter had already grown disillusioned, feeling that it was not receiving benefits at the federal level commensurate with its position as a coalition partner. ${ }^{58}$ The newly created Mid-Western Region, a NCNC stronghold which had been carved out of the Western Region a few months before the enumeration began, was given a population of 2.5 million (or 5 per cent of the total). Chief Dennis Osadebay, the premier of the Mid-Western Region, initially sided with Okpara in rejecting the count, but eventually accepted the census figures. ${ }^{59}$ In practice, Osadebay's acceptance of the figures isolated the East and provided a significant boost to the figures' legitimacy. ${ }^{60}$ Demographer I. Ekanem speculated that, due to Akíntọlá's alliance with the NPC, the North had given the Western Region higher figures. ${ }^{61}$ Regardless of the veracity of this allegation, Akíntọlá mobilized the satisfactory census results to consolidate his power in the Western Region and gain the support of many who had remained loyal to Awólọ́wọ̀ and the AG. ${ }^{62}$ Key NCNC politicians in the West turned their backs on Okpara, and joined Akíntọ́lá's latest creation, the Nigerian National Democratic Party. ${ }^{63}$ It is clear that the 1963 figures were not at the centre of a single, circumscribed 'census controversy', but rather were mobilized in different political scenarios by a wide range of historical actors with competing agendas. The remaining part of this paper follows a specific strand of the controversies over the 1963 results, limited to one site of narrative production and contestation. In what follows, we explore how the English-language press amplified the struggle over the construction of the 'North' and the 'East', in which the census played such a central role.

\footnotetext{
${ }^{54}$ For a concise introduction to the Western Region crisis, see Diamond, Class, Ethnicity and Democracy, 93-130.

${ }^{55}$ A. T. Balewa, 'Second count', in Mr Prime Minister: A Selection of Speeches Made by Alhaji the Right Honourable Sir Abubakar Tafawa Balewa, K.B.E., M.P., Prime Minister of the Federal Republic of Nigeria (Apapa, Nigeria, n.d.), 184-5.

${ }^{56}$ Aluko, 'How many Nigerians?', 384.

${ }^{57}$ 'East rejects census figures', West African Pilot, 29 Feb. 1964, 1.

${ }^{58} \mathrm{~T}$. Falola and M. Heaton, A History of Nigeria (Cambridge, 2008), 167.

${ }^{59}$ Interestingly, Osadebay also claimed that the 1952 figures should still be used to allocate parliamentary representation. 'Mid-West opposes census figures', Daily Mail, 2 Mar. 1964, 2.

${ }^{60}$ Diamond, Class, Ethnicity and Democracy, 145.

${ }^{61}$ Ekanem, 1963 Census, 96-7.

${ }^{62}$ Iro, Population Censuses of Nigeria, 72. Even before the 1963 count, the UPP had already used the census controversy to delegitimize the AG. 'UPP accuses AG on census', Daily Times, 10 Dec. 1962, 3.

${ }^{63}$ Diamond, Class, Ethnicity and Democracy, 141.
} 


\section{The census in the press: From enumeration and testing to ethnic stereotypes}

It is difficult to underestimate the importance of the press in Nigeria's political and cultural history. ${ }^{64}$ Under colonial rule, the country's future political leaders capitalized on the power of the printed word to consolidate reading publics, create diasporic spaces, and forge alliances and identities. ${ }^{65}$ In the 1960 s, newspapers contributed to the drawing of the contours of the ideological arena within which the battles for the country's postcolonial future would be fought and exacerbated preexisting conflicts. This was mirrored in an increasingly inflammatory rhetoric and an editorial landscape that closely reflected (and in large part contributed to the construction of) the ethnic constituencies of different political parties. ${ }^{66}$ The press inscribed the population figures within the wider canvas of the making and unmaking of the Nigerian nation in a variety of ways.

A first important narrative thread in the contestation of the 1963 figures centred around enumeration practices and tests. The testing was based on comparing three sets of figures: the actual census enumeration returns, an independent estimate based on a sample of enumeration areas for each census district, and the returns of the precensus house count exercise. ${ }^{67}$ For each of the more than 300 census districts into which the country had been divided, thirty enumeration areas were selected to be part of the sample. In all these enumeration areas, a local enumerator and an inspector from a different region (the latter being a novelty of the 1963 count) recorded the population. ${ }^{68}$ The house numbering exercise took place two weeks before the main enumeration. Enumerators were sent to identify all dwelling units and to obtain from the residents the number of people usually living there, divided by sex. ${ }^{69}$ In a press statement, Okpara listed the numerous reasons that forced him, as the Eastern Region's premier, to reject the count's results. ${ }^{70}$ A first significant problem was represented by the fact that the enumeration areas included in the sample, which should have remained secret until after the main enumeration was complete, were already made known in the North even before the count. What followed in Okpara's list of grievances was a series of specific accusations of malpractice and irregularities in counting that were allegedly observed firsthand by Eastern inspectors in the Northern Region. These included counting in market places (after the Census Board had decided to limit enumeration to people's houses and other specifically identified 'special areas' like hospitals, prisons, and universities), counting of travellers and passersby without staining their thumbs (thus allowing for the possibility that they would be counted again), and counting of persons not seen (in spite of the fact that the enumerators were supposed to count by sight). Okpara also maintained that Eastern inspectors were counted as part of the Northern population, thus contravening to the Census Board's decision that inspectors should have been included as part of their constituencies' population. ${ }^{71}$

What emerges from these accusations is a narrative about the micropolitics of falsification that describes it as a process that involved primarily the enumerators and the counted subjects in the field, rather than policy makers at the top levels of political decision-making. A particularly controversial aspect of Okpara's accusations, because it presented the process of enumeration as conflicting with established Northern cultural practices, was the alleged 'refusal of entry into purdah'.

\footnotetext{
${ }^{64}$ For a general survey, see D. Duyile, Makers of the Nigerian Press: An Historical Analysis of Newspaper Development, the Pioneer Heroes, the Modern Press Barons and the New Publishers from 1859-1987 (Ibadan, 1987).

${ }^{65}$ This process critically depended on negotiating forms of authorship and discursive spaces under colonial censorship. S. Newell, The Power to Name: A History of Anonymity in Colonial West Africa (Athens, OH, 2013).

${ }^{66}$ For further discussion of these aspects, see S. Badimuro, 'Press and politics in Nigeria's First Republic 1960-1966', Journal of the Historical Society of Nigeria, 11:3-4 (1982), 107-29; and W. Adebanwi, Nation as Grand Narrative: The Nigerian Press and the Politics of Meaning (Rochester, NY, 2016).

${ }^{67}$ The testing process is described in more detail in Iro, Population Censuses of Nigeria, 77-82.

${ }^{68}$ Ibid. 69.

${ }^{69}$ Ibid. 70.

${ }^{70}$ M. I. Okpara, 'Press statement on the census by Dr M. I. Okpara, Premier, Eastern Nigeria on Friday 28 February 1964', Enugu, n.d. A copy of the press statement can be found in TNA DO 195/344/10A.

${ }^{71}$ Ibid. $2-3$.
} 
Table 1. Magnitude, regional composition, and growth of the Nigerian population, 1931-63.

\begin{tabular}{|c|c|c|c|c|c|c|c|c|}
\hline \multirow[b]{2}{*}{ Region } & \multicolumn{4}{|c|}{$\begin{array}{c}\text { Population (in thousands and as } \% \text { of } \\
\text { total) }\end{array}$} & \multicolumn{4}{|c|}{ Intercensal growth (\%) } \\
\hline & 1931 & $1952-3$ & 1962 & 1963 & 1931 to $1952-3$ & $1952-3$ to 1962 & $1952-3$ to 1963 & $1931-63$ \\
\hline Northern & $\begin{array}{l}11,435 \\
(58 \%)\end{array}$ & $\begin{array}{l}16,840 \\
(55 \%)\end{array}$ & $\begin{array}{l}22,015 \\
(49 \%)\end{array}$ & $\begin{array}{l}29,809 \\
(54 \%)\end{array}$ & $47.3 \%$ & $30.7 \%$ & $77 \%$ & $160.7 \%$ \\
\hline Eastern & $\begin{array}{l}4,316 \\
(22 \%)\end{array}$ & $\begin{array}{l}7,218 \\
(24 \%)\end{array}$ & $\begin{array}{c}12,332 \\
(27 \%)\end{array}$ & $\begin{array}{l}12,394 \\
(22 \%)\end{array}$ & $67.2 \%$ & $70.9 \%$ & $71.7 \%$ & $187.2 \%$ \\
\hline Western & $\begin{array}{l}3,677 \\
(19 \%)\end{array}$ & $\begin{array}{l}6,087 \\
(20 \%)\end{array}$ & $\begin{array}{l}10,523 \\
(23 \%)\end{array}$ & $\begin{array}{l}10,266 \\
(18 \%)\end{array}$ & $65.5 \%$ & $72.9 \%$ & $110.3 \%$ & $248.2 \%$ * \\
\hline Mid-Western & - & - & - & $\begin{array}{l}2,536 \\
(5 \%)\end{array}$ & - & - & - & - \\
\hline Lagos & $\begin{array}{c}126 \\
(1 \%)\end{array}$ & $\begin{array}{c}272 \\
(1 \%)\end{array}$ & $\begin{array}{c}450 \\
(1 \%)\end{array}$ & $\begin{array}{l}665 \\
(1 \%)\end{array}$ & $115.9 \%$ & $65.4 \%$ & $144.5 \%$ & $427.8 \%$ \\
\hline Total & $\begin{array}{l}19,554 \\
(100 \%)\end{array}$ & $\begin{array}{l}30,417 \\
(100 \%)\end{array}$ & $\begin{array}{l}45,320 \\
(100 \%)\end{array}$ & $\begin{array}{l}55,670 \\
(100 \%)\end{array}$ & $55.6 \%$ & $49 \%$ & $83 \%$ & $184.7 \%$ \\
\hline
\end{tabular}

Source: Authors' calculations based on S. Jacob, Census of Nigeria, 1931, Volume I: Nigeria (London, 1933), 95, table 1; Nigeria Department of Statistics, Population Census of Nigeria 1952-53 (Lagos, 1953), 2, table 1; Federal Republic of Nigeria, Population Census of Nigeria 1963, Volume III: Combined National Figures (Lagos, n.d.), 52, 54-6. The figures attributed to the 1962 census, which were never officially published, are taken from M. Iro, 'The demography of Nigeria, 1950-1966: with special reference to the methods and accuracy of the population censuses during this period' (unpublished PhD thesis, Cornell University, 1973), 39.

Note: The 1931 figures exclude the Cameroons. The 1952-3 figures exclude the population of Southern Cameroons and the trust territories in the Adamawa, Benue, and Bornu Provinces. It should also be noted that the census was held in the Northern Region in June 1952, in the West and in Lagos in December 1952, and in the East in June 1953. The final figures reported refer to a midyear estimate of 1953; see Nigeria Department of Statistics, Population Census of Nigeria, 1, table A.

* All intercensal growth rate calculations for the Western Region, including the 1931-63 one, include the Mid-Western Region.

Because of this, enumerators were allegedly asked to accept at face value the number of wives and females declared by the head of the household. This claim constituted simultaneously a violation of counting by sight, one of the main principles of the census, and an invitation to consider how accounts of data collection procedures became intertwined with the derogatory crystallization of ethnic and cultural identities. Okpara's press statement also included some data on the distribution of districts that failed statistical tests relating to the population count in the four main regions (Lagos was excluded; see Table 2). He claimed that the Northern returns appeared suspicious because the districts that in theory had been randomly selected for testing displayed a suspiciously high level of homogeneity. Secondly, while it was assumed that it would have been difficult to enumerate more than 600 people per day, in several Northern districts more than 900 people had been enumerated in one day. Okpara was also surprised that the figures were published before applying sex and age ratio tests, which were designed to 'spot out any area that has been inflated'. ${ }^{72}$

A high proportion of districts failed some or all tests in the Western (57.4 per cent), Mid-Western (46.7 per cent), and Northern (43.4 per cent) Regions. At the national level, only 57.5 per cent of census districts passed all tests and, among those that did not, more than half failed all tests. However, in the Northern Region the severity of the problems identified was much greater. There, of those districts that did not pass all tests, 64.5 per cent failed all of them, compared to 37 per cent in the Western and 42.9 per cent in the Mid-Western Regions. According to Okpara, the significant extent of (and thus deliberate) miscounting in the Northern Region set it apart from the rest of Nigeria and led him to conclude that 'those guilty of inflation have condemned us all as a country incapable of conducting a Census'. ${ }^{73}$

Ahmadu Bello, the sardauna of Sokoto and premier of the Northern Region, promptly responded to Okpara's criticism. His strategy was simple: to take all the accusations made against the North and redirect them against the East. One was that the East, unlike the North, had refused

\footnotetext{
${ }^{72}$ Ibid. 4.

${ }^{73}$ Ibid. 5 .
} 
Table 2. Performance of census districts in statistical tests.

\begin{tabular}{|c|c|c|c|c|c|}
\hline \multirow[b]{2}{*}{ Region } & \multirow[b]{2}{*}{$\begin{array}{l}\text { Total number of } \\
\text { census districts }\end{array}$} & \multirow[b]{2}{*}{$\begin{array}{l}\text { Districts that passed all } \\
\text { tests (number and \% } \\
\text { total) }\end{array}$} & \multicolumn{3}{|c|}{ Districts that failed tests } \\
\hline & & & $\begin{array}{l}\text { Failed some or all tests } \\
\text { (number and \% total) }\end{array}$ & $\begin{array}{c}\text { Failed all } \\
\text { tests } \\
\text { (number and } \\
\% \text { total) }\end{array}$ & $\begin{array}{c}\text { Failed all tests } \\
\text { (as } \% \text { of districts } \\
\text { that failed some } \\
\text { tests) }\end{array}$ \\
\hline Northern & 175 & $\begin{array}{c}99 \\
(56.6 \%)\end{array}$ & $\begin{array}{c}76 \\
(43.4 \%)\end{array}$ & $\begin{array}{c}49 \\
(28 \%)\end{array}$ & $64.5 \%$ \\
\hline Eastern & 73 & $\begin{array}{c}53 \\
(72.6 \%)\end{array}$ & $\begin{array}{c}20 \\
(27.4 \%)\end{array}$ & $\begin{array}{c}5 \\
(6.8 \%)\end{array}$ & $25 \%$ \\
\hline Western & 47 & $\begin{array}{c}20 \\
(42.6 \%)\end{array}$ & $\begin{array}{c}27 \\
(57.4 \%)\end{array}$ & $\begin{array}{c}10 \\
(21.2 \%)\end{array}$ & $37 \%$ \\
\hline Mid-Western & 15 & $\begin{array}{c}8 \\
(53.3 \%)\end{array}$ & $\begin{array}{c}7 \\
(46.7 \%)\end{array}$ & $\begin{array}{c}3 \\
(20 \%)\end{array}$ & $42.9 \%$ \\
\hline Lagos & 3 & - & - & - & - \\
\hline Total & 313 & $\begin{array}{c}180 \\
(57.5 \%)\end{array}$ & $\begin{array}{c}130 \\
(41.5 \%)\end{array}$ & $\begin{array}{c}67 \\
(21.4 \%)\end{array}$ & $51.5 \%$ \\
\hline
\end{tabular}

Source: Authors' calculations based on Okpara, 'Press statement', 4.

to reestimate (and downsize) the population figures of the districts that had failed all other tests by using the housing counts (Table 3 ). ${ }^{74}$

In his response to Okpara, Bello added two elements that enriched seemingly factual statements about how the numbers were collected with further meanings and associations. The first was that, if anything, the impossibility of counting women by sight would have resulted in undercounting rather than overcounting. ${ }^{75}$ Second, Bello claimed that Eastern enumerators in the North did not have any incentive to contribute to the inflation of another region's figures. In theory, the use of inspectors from other regions should have ensured that the 1963 census represented a truly national enterprise that overcame 'tribalist' interests. ${ }^{76}$ However, the use of Eastern inspectors in the North resonated with a deep-seated cause of tension in the balance of political power. If Southern politicians felt threatened by the numbers of the North, which had been the legal basis on which their majority in the parliament was determined, the North had its own fears of having already become an object of Igbo economic domination. These fears were grounded in the dynamics of colonial rule, in which the disparity in English-language education led the British colonial administration to rely increasingly on southern Nigerians to administer the North. The sheer size of the North's population was presented in turn as the basis on which the Northern Region could expose what it perceived as an unjust oppression. This can be observed in the cartoon below from the Northern daily Nigerian Citizen (Fig. 1).

The Igbo man tells the northerners, 'You guys do not have enough education to work', but the cartoonist's choice to make him speak in pidgin was possibly meant to undermine the credibility of this self-representation. The North's resentment at what was seen as the Igbo control of trade and administration had been since the 1950s one of the main drivers behind the "Northernization policy."

In the southeast, discussions of the North's stance informed a wide range of publications, cutting across different genres and formats. This could be observed in Onitsha, the city which hosts Nigeria's largest popular literature market. ${ }^{78}$ An anonymous pamphlet on the census controversy

\footnotetext{
${ }^{74}$ Sardauna Accepts Census Figures - Answers Critics One by One (Zaria, Nigeria, n.d.), 5.

${ }^{75}$ Ibid.

${ }^{76}$ Ibid.

${ }^{77}$ For further discussion on this, and a detailed account of the life of the Igbo community in Kano, see D. Anthony, Poison and Medicine? Ethnicity and Identity in a Northern Nigerian City, 1966-1986 (Portsmouth, NH, 2002).

${ }^{78}$ On the literary, linguistic, and organizational features of Onitsha market literature, see D. Nwoga, 'Onitsha market literature', Transition, 19 (1965), 26-33; the anthology by E. Obiechina (ed.), Onitsha Market Literature (London, 1973); D. Dodson, 'The role of the publisher in Onitsha market literature', Research in African Literatures, 4:2 (1973); and
} 
Table 3. Returns of alternative population counts and estimates, and their contribution to the 1963 official figure.

\begin{tabular}{|c|c|c|c|c|c|}
\hline Region & $\begin{array}{c}\text { Census } \\
\text { enumeration }(\mathrm{A}) \\
\text { (total and as \% } \\
\text { of } \mathrm{P}^{\star} \text { ) }\end{array}$ & $\begin{array}{l}\text { Estimate based on } \\
\text { sample }(\mathrm{B}) \\
\text { (total and as } \% \text { of } \mathrm{P}^{\star} \text { ) }\end{array}$ & $\begin{array}{l}\text { House numbering count }(\mathrm{C}) \\
\text { (total and as } \% \text { of } \mathrm{P}^{\star} \text { ) }\end{array}$ & $\begin{array}{c}\text { Contribution of } A, B \text {, and } C \text { to the accepted and official } \\
\text { population figures (total and as } \% \text { of } \mathrm{P}^{*} \text { ) }\end{array}$ & $\begin{array}{c}\text { Accepted } \\
\text { population figure } \\
\left(\mathrm{P}^{\star}\right)\end{array}$ \\
\hline Northern & $\begin{array}{c}32,546,368 \\
(109.2 \%)\end{array}$ & $\begin{array}{l}29,519,204 \\
(99 \%)\end{array}$ & $\begin{array}{l}27,652,414 \\
(92.8 \%)\end{array}$ & $17,052,059(57.2 \%)+8,205,442(27.5 \%)+4,550,958(15.3 \%)$ & $29,808,659$ \\
\hline Eastern & $\begin{array}{c}12,857,672 \\
(103.7 \%)\end{array}$ & $\begin{array}{c}11,944,519 \\
(96.4 \%)\end{array}$ & $\begin{array}{l}9,291,105 \\
(75 \%)\end{array}$ & $9,097,467(73.4 \%)+875,912(7.1 \%)+2,421,083(19.5 \%)$ & $12,394,462$ \\
\hline Western & $\begin{array}{c}11,267,277 \\
(109.8 \%)\end{array}$ & $\begin{array}{l}9,733,529 \\
(94.8 \%)\end{array}$ & $\begin{array}{c}8,170,184 \\
(79.6 \%)\end{array}$ & $5,744,628(56 \%)+1,841,406(17.9 \%)+2,679,812(26.1 \%)$ & $10,265,846$ \\
\hline Mid-Western & $\begin{array}{c}2,715,597 \\
(107.1 \%)\end{array}$ & $\begin{array}{c}2,513,859 \\
(99.1 \%)\end{array}$ & $\begin{array}{c}1,923,383 \\
(75.8 \%)\end{array}$ & $1,276,996(50.4 \%)+549,588(21.7 \%)+709,255(28 \%)$ & $2,535,839$ \\
\hline Lagos & $\begin{array}{l}665,246 \\
(100 \%)\end{array}$ & - & - & - & 665,246 \\
\hline Total & $\begin{array}{c}60,052,136 \\
(107.9 \%)\end{array}$ & $\begin{array}{c}53,711,111 \\
(96.5 \%)\end{array}$ & $\begin{array}{c}47,037,086 \\
(84.5 \%)\end{array}$ & $33,836,246(60.8 \%)+11,472,348(20.6 \%)+10,361,108(18.6 \%)$ & $55,670,052$ \\
\hline
\end{tabular}

Source: Iro, Population Censuses of Nigeria, 76. 


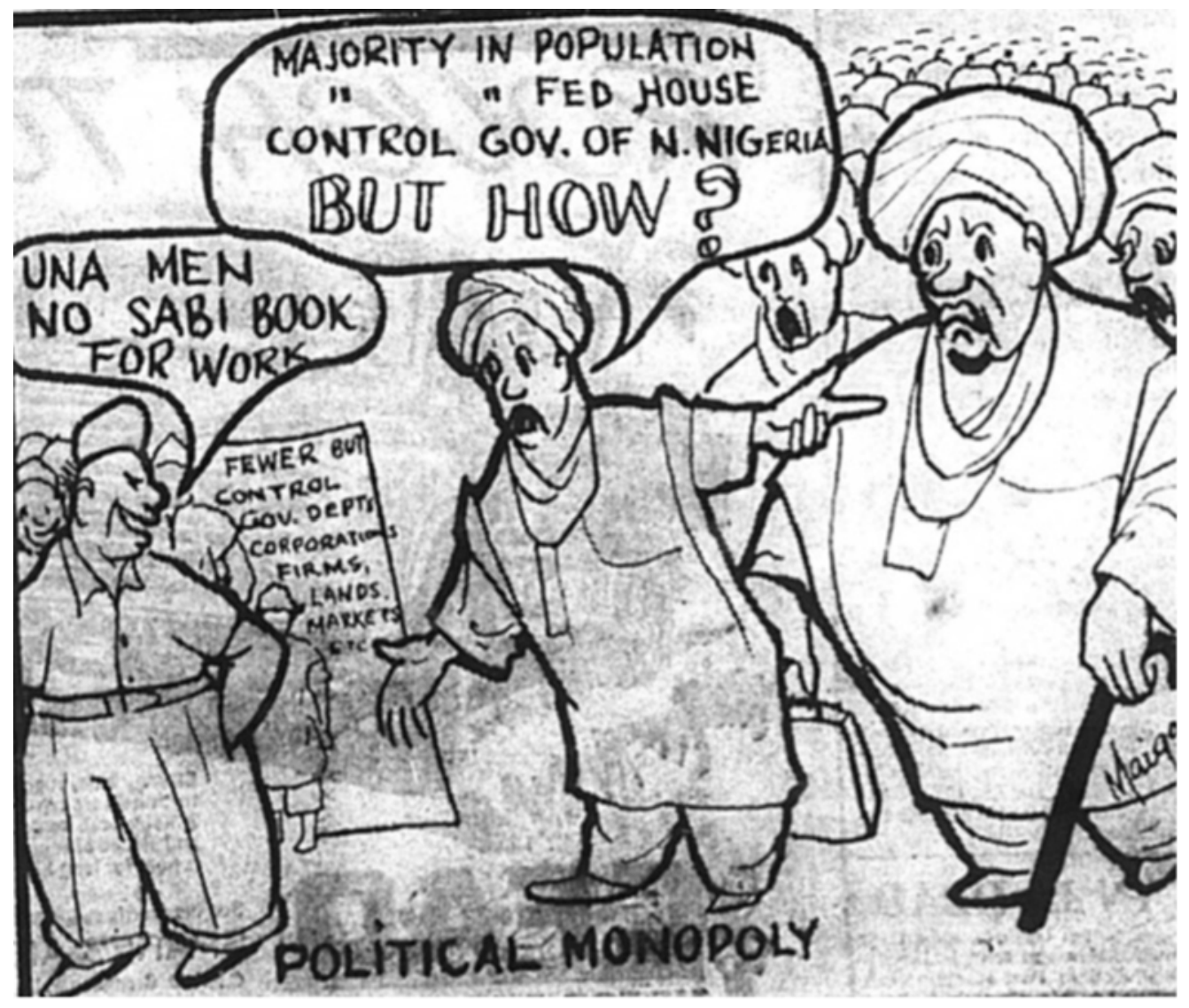

Figure 1. 'Political monopoly'.

Source: Nigerian Citizen, 18 Apr. 1964, 1.

published there (Fig. 2) reported the Northern premier's (and Prime Minister Abubakar Tafawa Balewa's) denials of the accusations that some Igbos living in the North had had their lands and properties expropriated, but also called for a commission of inquiry to shed light on the matter. ${ }^{79}$ If the commission of inquiry found evidence of expropriation, the anonymous author of the pamphlet maintained that it would be necessary to declare a state of emergency. ${ }^{80}$

The Ibo State Union published excerpts of the parliamentary debates in the Northern House of Assembly. ${ }^{81}$ These quotations reveal the full extent to which the census controversy became intertwined with the poisonous rhetoric of interethnic conflict. In the face of the Igbo people's supposed 'cheating with the census', the solutions envisaged by some members of the Northern parliament included the revocation of Igbo individuals' occupancy licences, the confiscation of their land and properties, and their deportation. ${ }^{82} \mathrm{~A}$ delegate called for the revocation of immigrants' medical licences because he thought that Igbo doctors would use them 'to administer medicine to kill most of our people'. ${ }^{83}$

S. Newell, 'From the brink of oblivion: the anxious masculinism of Nigerian market literatures', Research in African Literatures, 27:3 (1996), 50-73.

${ }^{79}$ Hausas and Ibos in a Political Fight towards the 1963 Census Figures, (Onitsha, n.d.), 5-12.

${ }^{80}$ Ibid. 7.

${ }^{81}$ Ibo State Union, Census Controversy: One North or One Nigeria? (Enugu, Nigeria, n.d.).

${ }^{82}$ Ibid.

${ }^{83}$ The delegate was Alhaji Sarkin Daji Lafia, speaking on 14 Mar. 1964. Ibo State Union, Census Controversy, 17. 


\section{HAUSAS AND IBOS}

IN A POLITICAL

FIGHT TOWARDS THE

196: CENSUS FIGUIRHS

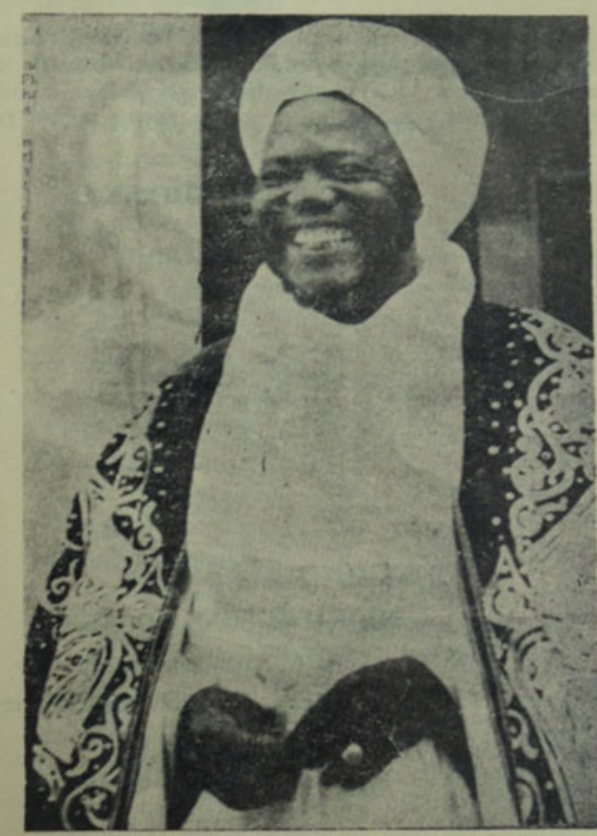

ALHAJI AHMADU BELLO PREMIER OF NORTHERN NIGERIA “'SAYS NO LAND SEIZURE IN NORTH",
Figure 2. Back cover of the pamphlet Hausas and Ibos in a Fight towards the 1963 Census Figures (Onitsha, n.d.).

The Ibo State Union concluded that this 'war of attrition' represented 'an organised attempt to annihilate a group of people for whom the Republic's Constitution guarantees common citizenship and fundamental rights. ${ }^{84}$ This claim could be read as a commentary on ethnic violence targeting the Igbo communities in the North, and as a premonition of the tragedy that would unfold during the Nigeria-Biafra war. $^{85}$

Although occasionally the press tried to placate the census crisis, several newspapers deployed the census results to promote stereotypical and provocative representations of cultural and ethnic traits. ${ }^{86}$ For example, the West African Pilot, the mouthpiece of Okpara's NCNC, published a cartoon showing a lonely herder, swinging a whip, directing cattle (Fig. 3).

The image provides a visual representation of the widely held rumour that the North's population figure was so high because cattle, as well as people, were enumerated. ${ }^{87}$ More generally, the cartoon

\footnotetext{
${ }^{84}$ Ibo State Union, Census Controversy, 22.

${ }^{85}$ For a recent discussion of the Biafra war and its broader implications, see L. Heerten, The Biafran War and Postcolonial Humanitarianism: Spectacles of Suffering (Cambridge, 2017).

${ }^{86}$ O. Bassir, 'Census: what we must do now', Morning Post, 11 Mar. 1964, 5.

${ }^{87}$ E. Osaghae, Crippled Giant: Nigeria since Independence (Bloomington, IN, 1998), 41. Rumours about this practice, combined with the immigration of people residing in Chad or Niger during the enumeration, still persist. On the 2006 census, see
} 


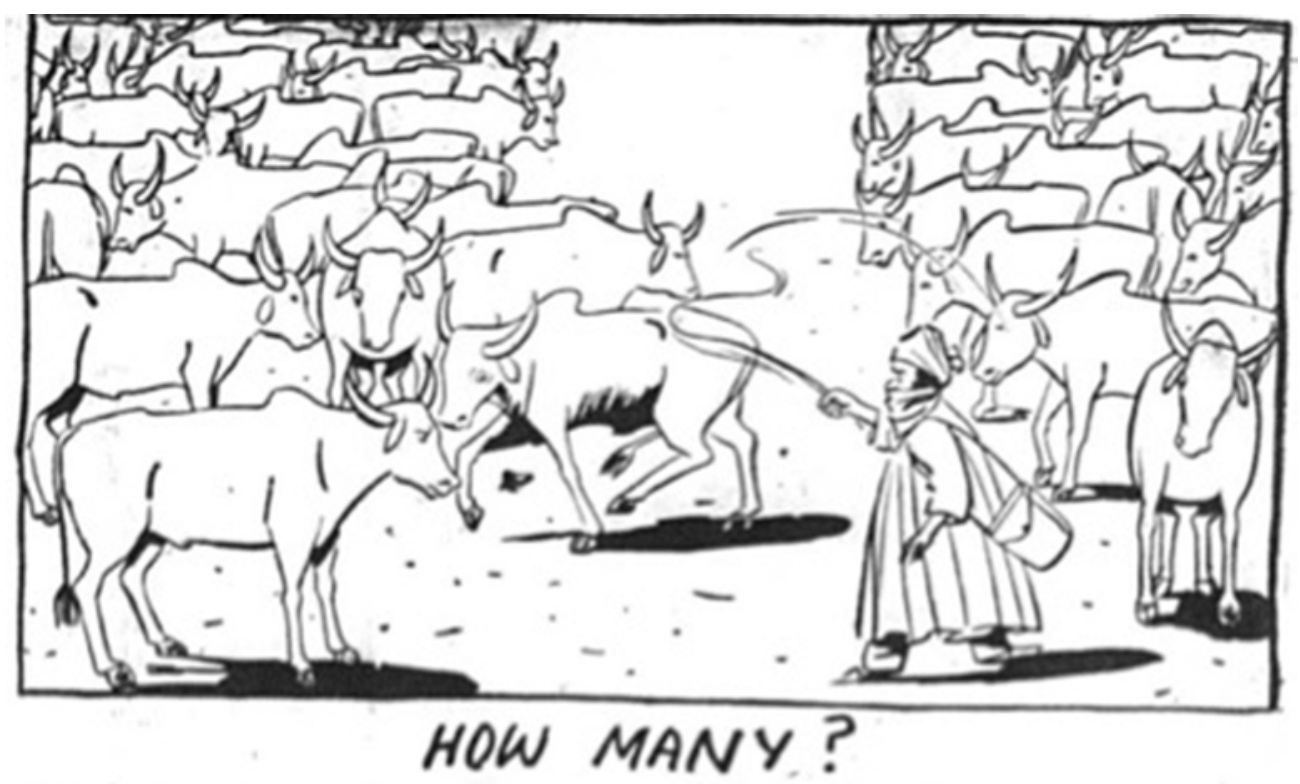

Figure 3. 'How many?'.

Source: West African Pilot, 31 Mar. 1964, 1.

reiterated the vision of the North as a vast but empty space and of northerners as 'backwards' pastoralists. Population density - which, with the exception of Lagos, was on average highest in the East (420 persons per square mile) and lowest in the North (106 persons per square mile) - became a recurring trope in the contestation of the figures, with the East claiming that the northern population returns were too high given the low population density of the region. ${ }^{88}$ It should also be noted that in some parts of the North (like in the Sokoto Caliphate, for example) the most important form of counting for social and political purposes involved the enumeration of cattle, which was central to estimating people's wealth and taxation, disputes over succession, and alms giving. ${ }^{89}$ If read in connection with the accusations raised about the impossibility of counting women by sight, this cartoon seems also to suggest that the cultural traits associated with the North were an obstacle to a 'modern' state that found in counting people, rather than cattle, its main enumerative practice. ${ }^{90}$ Meanwhile, in the northern city of Kano, the Nigerian Citizen had also been producing derogatory narratives (Fig. 4).

This incendiary cartoon suggested that the population gap between the North and the East was not the consequence of the North's deliberate attempt at manipulating the figures, but rather the result of cannibalism in the East. The West African Pilot republished it as evidence of the hateful campaign conducted in the North: 'We do not think the way to foster unity and a sense of belonging

N. Saro-Wiwa, Looking for Transwonderland: Travels in Nigeria (London, 2012), 191. The cartoon might also suggest that, because of their extreme mobility, gaining an accurate count of herders was particularly complicated.

${ }^{88}$ Federal Republic of Nigeria, Population Census 1963, Volume III (Lagos, 198), 52, 54. See, for example, Chief Okwu 'X-ray into census figures', Nigerian Outlook, 28 Mar. 1964, 4.

${ }^{89}$ Thanks to Gerd Spittler for inviting us to reflect on this aspect.

${ }^{90}$ Igbos' self-representation as 'modern' in contrast with the backwardness of the North acquired more dramatic connotations during the Biafra War. See D. Anthony, “Resourceful and progressive blackmen”: race and identity in Biafra, 19671970', The Journal of African History, 51:1 (2010), 41-61. On the other hand, scholarship has documented how different forms of modernity were negotiated and experienced in Northern Nigeria; see B. Larkin, Signal and Noise: Media, Infrastructure, and Urban Culture in Nigeria (Durham, NC, 2008); and M. Ochonu, 'Colonial itineraries: Muhammadu Dikko's metropolitan adventures', The Journal of African History, 61:2 (2020), 179-200. 


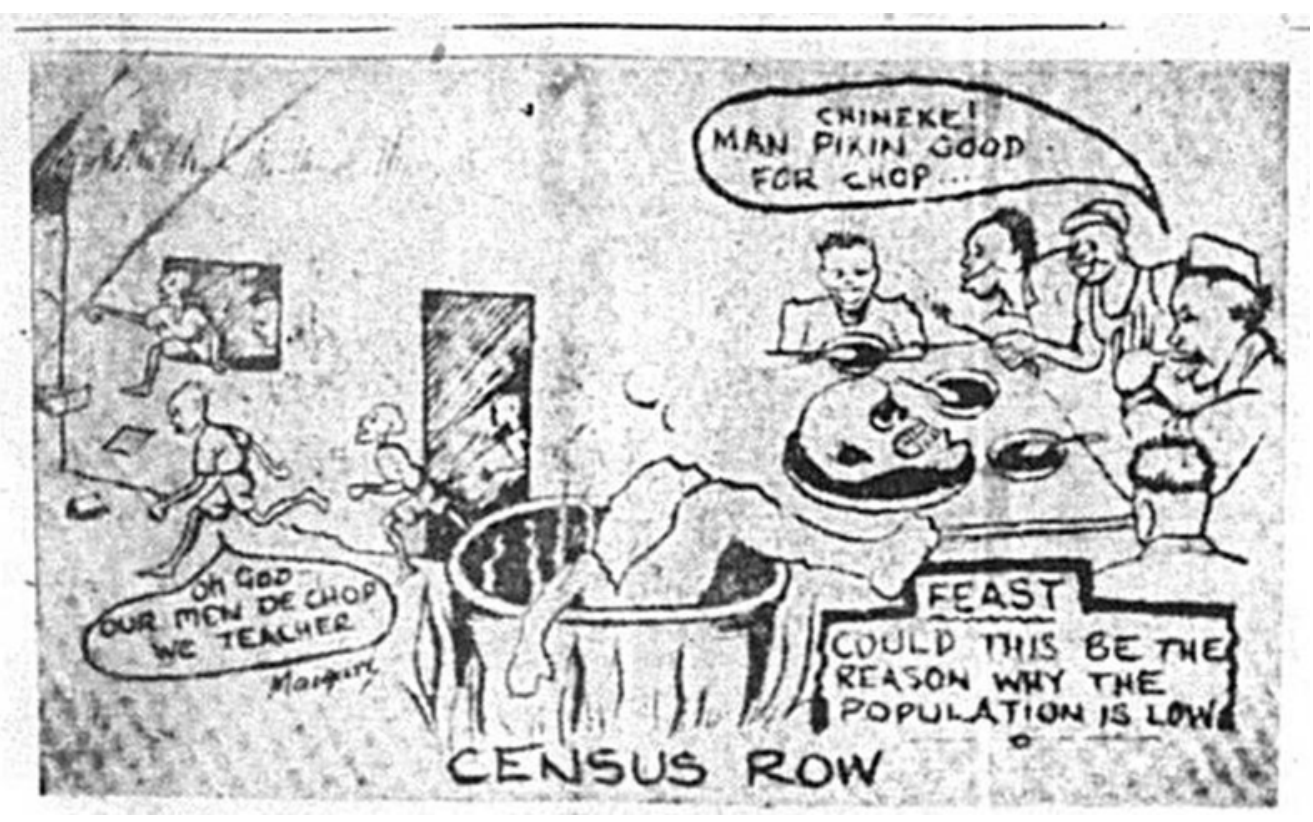

Figure 4. 'Census row'.

Source: Nigerian Citizen, 7 Mar. 1964, 1.

to "one family" is to show one section of the Nigerian community as cannibals." ${ }^{91}$ Two Igbo men sent indignant letters to the Nigerian Citizen, accusing Malam Maigari, the author of the cartoon, of an 'ignorant and low mentality' and asking him for evidence to support his claim. ${ }^{92}$ Maigari responded that 'it happened during the Colonial rule'. ${ }^{93}$ This exchange points at the importance of representations of the colonial period in Northern discourse about the census. First, this acceptance of the veracity of colonial knowledge was true for the census figures: the North's claim that their figures were more accurate than those produced by the South was based on the firm acceptance of the supposed fact that colonial censuses were fundamentally accurate. For example, in his response to Okpara's statement, the premier of the Northern Region, Ahmadu Bello, quoted the 1931 figures (which were highly unreliable) as the basis of his claim that, since the 1930s, the North's population had grown much less than that of the West, the East, or the national average (see Table 1). ${ }^{94}$ Similarly, the North rejected the results of the 1962 census on the basis that a 71 per cent growth in the East's population between 1953 and 1962 must have been the consequence of an overcount in the postcolonial census, rather than an undercount in the colonial one. ${ }^{95}$ Finally, the reference to colonial rule as a time in which cannibalism was widespread among the Igbos echoed accounts

\footnotetext{
${ }^{91}$ 'Provocation', West African Pilot, 20 Mar. 1964, 1.

${ }^{92}$ 'Your letters', Nigerian Citizen, 21 Mar. 1964, 4.

${ }^{93}$ Ibid.

${ }^{94}$ Sardauna Accepts Census Figures, 3. However, our calculations in Table 1 indicate a growth rate for the West smaller (248 per cent) than that quoted by Ahmadu Bello (256 per cent). The undercount in the 1931 Eastern census figures is presumed to have been particularly severe due to tax riots in Aba, Onitsha, and Owerri. The North, on the other hand, was dealing with a locust invasion that diverted the efforts of an already understaffed colonial administration; see M. Jerven, Poor Numbers: How We Are Misled by African Development Statistics and What To Do About It (Ithaca, NY, 2013), 57. Polly Hill went as far as to say that the 1931 Northern figure was 75 per cent too low; see P. Hill, Population, Prosperity and Poverty: Rural Kano, 1900 and 1970 (Cambridge, 1977), 18.

${ }^{95}$ Emphasis on colonial undercounting, while maintaining the overall accuracy of the 1963 results, was placed by the influential journalist Ebenezer Williams; see E. Williams, 'The elephant is a fact-let's talk frankly, person to person, about the census', Morning Post, 4 Mar. 1964.
} 
written by missionaries. ${ }^{96}$ The Nigerian press contributed to the drawing of new spatial and temporal coordinates along which the nation could elaborate the relationship between its present and its future. ${ }^{97}$ This could lead to novel and imaginative representations of political belonging, but also, as in the case of census-inspired cartoons, to the recycling of tropes of the colonial imagination and a diminished possibility of envisaging a postcolonial future of unity and harmonious coexistence. Nor did such strains only occur through the consolidation of ethnic identities. By inscribing the census within narratives of ineptitude, the press amplified ordinary Nigerians' negative perceptions of the political and administrative establishment as a whole:

The nation is ashamed of counting and recounting itself. I know politicians are used to asking for a recount. It was said of one of them that when he was told his wife had given birth to triplets, he demanded a recount! I agree with those who cried out that the figures are astronomical. . . . But I cannot say how, or who juggled with the figures. I cannot say on oath who in the North, or the East or the West committed forgery. . . . May God give us strength and wisdom to battle against the gathering storm. ${ }^{98}$

If the joke about the politician asking for a recount of his own children is a reminder of the importance of humour in criticizing ruling elites, the article's overall tone was one of uncertainty and anxiety. ${ }^{99}$ Sixty years later, the conflicting rumours and questions about whose actions and agendas shaped the figures remain pressing.

\section{Conclusions}

The final act of the First Republic's battle over the 1963 census figures shifted the terrain of contestation from the realm of the printed word to that of the rule of law. On 18 May 1964, the Eastern Region filed a suit against the federal government to prove that the 1963 census was 'illegal and unconstitutional' and thus had to be declared 'null and void'. ${ }^{100}$ It was the first time that a regional government sued the federal government in the Supreme Federal Court, thus marking a potentially destabilizing precedent for the country's politics. The Supreme Federal Court, however, dismissed the Eastern motion. ${ }^{101}$ The figures were 'accepted' and projections based on them used as the basis of social and economic planning. ${ }^{102}$ The 1964 federal elections, conducted in an atmosphere of violence and intimidation, created a parliamentary allocation that mirrored the close link between political parties, regions, and their ethnic constituencies, thus highlighting the political significance of the census. ${ }^{103}$ Although they played a significant role in undermining the fragile foundations of the First Republic, the 1963 figures had a longer lifespan due to the repression of the census held by Yakubu Gowon's military government in 1973. Indeed, the next census that would be accepted took place only in 1991.

\footnotetext{
${ }^{96} \mathrm{G}$. Basden, Among the Ibos of Nigeria: An Account of the Curious \& Interesting Habits, Customs and Beliefs of a Little Known African People By One Who Has For Many Years Lived Amongst Them On Close and Intimate Terms (London, 1921$), 40$.

${ }^{97}$ L. James, 'The flying newspaperman and the time-space in late colonial Nigeria', Comparative Studies in Society and History, 60:3 (2018), 569-98.

${ }^{98}$ Allah-De, 'Talking census ...', Sunday Times, 1 Mar. 1964, 10. The Census Commission itself was victim of a fraud, leading to the disappearance of several hundred pounds that should have been used to pay the services of enumerators and inspectors. See 'Census fraud mystery!', Sunday Express, 8 Dec. 1963, 1-2.

${ }^{99}$ On this aspect, see E. Obadare, Humour, Silence and Civil Society in Nigeria (Rochester, NY, 2016).

${ }^{100 ،}$ 'Census row goes to court - East sues Fed. Gov.', West African Pilot, 19 May 1964, 1.

${ }^{101}$ Attorney-General, Eastern Nigeria v. Attorney-General of the Federation, The All Nigeria Law Reports (1964), 218-26.

${ }^{102} \mathrm{~A}$ growth rate of 2.5 per cent from a 1963 base was adopted until 1976, when the assumed population growth rate was adjusted to 3.2 per cent. Jerven, Poor Numbers, 58.

${ }^{103}$ R. Udo, 'Population and politics in Nigeria (problems of census-taking in the Nigerian Federation)', in Caldwell and Okonjo, Population of Tropical Africa, 97-105.
} 
In spite of the many discontinuities that marked the political landscape of postcolonial Nigeria, the census has continued to play a crucial role as an allocative framework, as a template through which ordinary Nigerians make claims vis-à-vis (or about) the state, and as a platform for contestation. ${ }^{104}$ Over the years, Nigerian scholars and policy makers have repeatedly pleaded for the necessity of 'depoliticising' the census, thus reinforcing a dichotomous distinction between the 'political' and 'technical' aspects of population counting. ${ }^{105}$ But what is political about census taking to begin with? Our exploration has blurred the boundaries between the two and has pointed to the malleability of the census in the political imagination. This paper has focused on print cultures as one possible avenue for simultaneously broadening our understanding of the politics of counting people and showing how it works in the public sphere. In spite of their diversity, the ethnically charged cartoons in daily newspapers and the claims about enumeration practices and tests made by Ahmadu Bello and Michael Okpara should be understood as part of the same discursive framework, which used the census as a foil to reflect fears of domination and produce representations of 'alterity'. Seemingly 'factual' statements about data collection procedures or population density fed a divisive political imagination. The census exacerbated the conflict between different groups and, in the process, led to their redefinition as either regions, ethnic groups, or cultural formations. It has been shown that the history and historiography of population counting in Africa are rife with such examples. However, in contrast with the literature's emphasis on identification, categorization, and enumeration, we suggest that the Nigerian census acquired crucial meanings and implications by inspiring a plethora of visual and textual representations.

A close look at these representations indicates that the politics of counting people cannot be reduced to the political economy of population figures. Nor should it be confined to the census forms' reification of ethnic and racial categories or to the encounter between the enumerated subjects and the statistical apparatus. Instead, it should interrogate the many other ways in which numbers shape the discourse about public trust, identity, and the state. ${ }^{106}$ Studying the census as a trope in print cultures is one of many ways in which demographic historians of Africa can broaden their gaze and reflect on how, through their appropriation and circulation in the public sphere, population figures tell stories and create meaning.

Acknowledgements. Previous versions of this paper were presented at the Institut d'Études Avancées de Nantes; the Institut d'Études Politiques de Rennes; the Institut Français de Recherche en Afrique, Ibadan; the Department of History, University of Ibadan; and the Third European Society of Historical Demography Conference (Pécs, 2019). We are grateful to these events' organisers and participants, as well as to Olutayo Adesina, Steven Pierce, and the reviewers for their insightful comments. Gerardo Serra would like to thank Elodie Apard, Clémentine Chazal, the entire IFRA staff, and Olutayo Adesina for their kind hospitality in Ibadan; as well as the University of Sussex's History Department and the University of Manchester's School of Arts, Languages and Cultures for funding archival trips in Britain, USA, and Nigeria. Morten Jerven's research was supported by Noragric (Norwegian University of Life Sciences) and funding from Lund University and the Swedish Research Council for 'African States and Economic Development in the 20th Century: Capacity to Count and Collect' (2017-05564). COVID prevented returning to Nigeria to gather further archival material and oral testimonies. Thanks are due to the librarians and archivists of the institutions preserving the sources on which this paper is based: Oxford's Bodleian Library, the British Library, the British Library of Development Studies (Sussex), Northwestern University's Melville J. Herskovits Library, Duke University's David M. Rubenstein Library, the National Archives of the United Kingdom (London), and the Ibadan branch of the National Archives of Nigeria. All errors remain our responsibility. Authors' emails: gerardo. serra@manchester.ac.uk, morten.jerven@nmbu.no.

\footnotetext{
${ }^{104}$ On the contestation of the 2006 census, see B. Adele, 'Falsification of population census data in a heterogeneous Nigerian state: the Fourth Republic example', African Journal of Political Science and International Relations, 3:8 (2009), 311-19.

${ }^{105}$ A. Adepoju, Technical and Political Aspects of Population Enumeration in Nigeria (Ile-Ife, Nigeria, 1983); Obono and Omoluabi, 'Technical and political aspects'. For a critique of this dichotomy in a different context, see M. Jerven, 'Beyond precision: embracing the politics of global health numbers', The Lancet, 392:10146 (2018), 468-9.

${ }^{106}$ See Serra, 'Hail the census night'.
}

Cite this article: Serra G, Jerven M (2021). Contested Numbers: Census Controversies and the Press in 1960s Nigeria. The Journal of African History 62(2), 235-253. https://doi.org/10.1017/S0021853721000438 